\title{
Keseimbangan dan Kelentukan Pergelangan Kaki: Bagaimanakah Korelasinya dengan Kemampuan Shooting Sepakbola?
}

\section{Dewonggo Sinatriyo, Indra Jati Kusuma, Rifqi Festiawan, Kusnandar, Fuad Noor Heza}

Program Studi Pendidikan Jasmani, Fakultas Ilmu Kesehatan,

Universitas Jenderal Soedirman, Indonesia

Diterima: 06 April 2020. Direvisi: 08 Juni 2020. Disetujui: 02 Juli 2020

\begin{abstract}
ABSTRAK Tujuan penelitian ini adalah untuk mengetahui korelasi keseimbangan dan kelentukan pergelangan kaki dengan kemampuan shooting siswa peserta ekstrakurikuler sepakbola SMP Negeri 2 Kembaran Banyumas. Metode penelitian ini adalah korelasional dengan pendekatan cross sectional, teknik sampling menggunakan purposive sampling dengan kriteria inklusi dan ekslusi dan diperoleh sampel sebanyak 60 siswa. Instrumen penelitian yang digunakan meliputi Diagonal Dynamic Balance Test (Roy \& Ghosh, 2017) dan kelentukan pergelangan kaki \& Shooting (Widiastuti, 2015). Teknik analisis data yang digunakan adalah uji korelasi pearson product moment dan korelasi ganda. Dari hasil penelitian diketahui bahwa tidak ada korelasi antara keseimbangan dengan kemampuan shooting den-

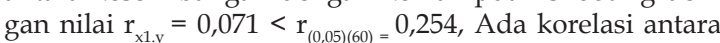
kelentukan pergelangan kaki dengan kemampuan shooting dengan nilai $r_{x 2 . y}=0,341>r_{(0,05)(60)}=0,254$, dan Tidak ada korelasi antara keseimbangan dan kelentukan pergelangan kaki dengan kemampuan shooting dengan nilai $r_{x 1 \times 2}$ $=0,129<\mathrm{r}_{(0,05)(60)=} 0,254$, dari hasil tersebut dapat diperoleh kesimpulan bahwa tidak ada korelasi antara keseimbangan dan kelentukan pergelangan kaki dengan kemampuan shooting.
\end{abstract}

Kata Kunci: Keseimbangan, Kelentukan, Kemampuan Shooting, Sepakbola

ABSTRACT The purpose of this study was to determine the correlation between ankle balance and flexibility and the shooting ability of students participating in soccer extracurricular at SMP Negeri 2 Kembaran Banyumas. This research method is correlational with cross sectional approach, the sampling technique uses purposive sampling with inclusion and exclusion criteria and a sample of 60 students is obtained. The research instruments used include the Diagonal Dynamic Balance Test (Roy E Ghosh, 2017) and ankle elasticity $\mathcal{E}$ shooting (Widiastuti, 2015). The data analysis technique used is Pearson product moment correlation test and multiple correlation. From the results of the study note that there is no correlation between balance with shooting ability with a value of $r x 1 . y=0.071<r(0.05)(60)=0.254$, there is a correlation between ankle flexibility with shooting ability with a value of $r x 2 . y=0.341>r(0.05)(60)=0.254$, and there is no correlation between ankle balance and flexibility and shooting ability with $r x 1, x 2, y=0.129<r(0.05)(60)=0.254$, from the results It can be concluded that there is no correlation between balance and ankle flexibility and shooting ability.

Keywords: Balance, Determination, Flexibility, Shooting Ability, Football

\section{PENDAHULUAN}

Sepakbola merupakan salah satu olahraga yang sangat populer di Indonesia, permainan ini merupakan permainan masyarakat yang bukan hanya dimainkan oleh kalangann profesional saja namun juga dimainkan oleh kalangan masyarakat umum tidak terkecuali siswa sekolah (Festiawan et al., 2019).

Saat ini, kompetisi sepakbola antar siswa sudah sangat menjamur, namun jika hanya mengacu pada kurikulum pembelajaran, maka siswa tidak akan mengembangkan bakat yang dimilikinya, sehingga selain kegiatan intrakurikuler, kita mengenal pula istilah kegiatan ekstrakurikuler.

Ekstrakurikuler sepakbola juga menjadi salah satu ekstrakurikuler yang banyak diminati oleh siswa sekolah saat ini, karena olahraga ini yang menyenangkan untuk dimainkan dan banyak kompetisi yang dapat diikuti.

Sepakbola sendiri merupakan olahraga yang berkembang sejak zaman cina kuno hingga sekarang, permainan ini dimainkan oleh dua tim yang masing-masing tim terdiri dari sebelas orang yang bermain dilapangan. Kemenangan dalam sepakbola ditentukan dari jumlah banyaknya mencetak gol ke gawang lawan dan dibatasi waktu selama 90 menit pertandingan (Bryson, 2012). Dalam sepakbola, ada banyak teknik dasar yang perlu dikuasai, diantaranya teknik passing, dribbling, shooting dan heading (Istofian \& Amiq, 2016).

Shooting merupakan salah satu teknik dasar dalam permainan sepakbola yang memiliki peranan penting, yaitu untuk mencetak gol ke gawang lawan (Jibriel, 2013). Dalam penguasaan teknik shooting ada beberapa aspek yang mendukung diantaranya kekuatan, kelentukan, kecepatan dan power, dengan kombinasi 
yang baik dapat menghasilkan kualitas shooting yang baik juga (Saifuddin \& Abdurrahman, 2017).

Selain aspek diatas, agar dapat memiliki kemampuan shooting yang baik, harus didukung dengan unsur-unsur penunjang lain yang saling berkaitan. Unsur-unsur itu adalah kemampuan fisik, kekuatan mental, status gizi, serta penguasaan teknik yang baik (Budiyono et al., 2018). Semua unsur tersebut sangat dibutuhkan dalam melakukan shooting. Kemampuan fisik menjadi salah satu unsur dominan penunjang kualitas shooting (Putra \& Ridwan, 2010).

Dari hasil studi awal, diperoleh hasil bahwa kemampuan shooting siswa peserta ekstrakurikuler sepakbola di SMP N 2 Kembaran masuk dalam kategori kurang dengan presentase 41,25\%. Hal ini didasari karena beberapa faktor, diantaranya ketidaktahuan siswa terkait teknik dasar shooting yang baik dan benar, kemampuan fisik yang masih belum maksimal, serta faktor anthropometri yang bervariatif dari siswa peserta ekstrakurkuler di SMPN 2 Kembaran.

Sementara itu dari kajian literatur terdahulu diketahui bahwa penelitian dari (Mubarok, 2011) terdapat hubungan antara power otot tungkai, koordinasi mata kaki, dan keseimbangan dengan kemampuan shooting, sedangkan, (Wibowo, 2015) menyebutkan bahwa terdapat hubungan antara kekuatan otot tungkai dan kelentukan pergelangan kaki terhadap keterampilan shooting.

Latar belakang dan beberapa hasil penelitian tersebut menjadi dasar dari penelitian yang dilakukan untuk mengetahui korelasi antara keseimbangan dan kelentukan pergelangan kaki dengan kemampuan shooting ini.

\section{METODE}

Desain penelitian ini menggunakan desain korelasional dengan pendekatan cross sectional yang bertujuan untuk mengetahui hubungan antara keseimbangan tubuh dan kelentukan pergelangan kaki dengan kemampuan shooting. Penelitian ini dilaksanakan di SMP Negeri 2 Kembaran Banyumas, dan dilaksanakan pada bulan Januari 2019. Populasi yang digunakan dalam penelitian ini merupakan siswa ekstrakurikuler sepakbola SMP Negeri 2 Kembaran Banyumas yang berjumlah 108 siswa. Teknik sampling menggunakan purposive sampling, dengan kriteria sebagai berikut: 1) Siswa kelas VII \& VIII yang aktif pada ekstrakurikuler sepakbola. 2) Mau menjadi sampel penelitian. 3) Jenis kelamin lakilaki, sehat jasmani \& rohani. Instrumen yang akan digunakan diantaranya: 1) Diagonal Dynamic Balance Test. 2) tes yang digunakan merupakan tes kelentukan pergelangan kaki dari widiastuti (2015). 3) Kemampuan Shooting, intrumen yang digunakan merupakan instrumen dari (Widiastuti, 2015).

Analisis data yang digunakan antara lain: Uji prasyarat yang terdiri dari, 1) Uji Normalitas data menggunakan uji Kolmogorov Smirnov. 2) Uji Linearitas Data, yang diuji dengan metode Ramsey. 3) Uji Homogenitas Data. Analisis berikutnya adalah Uji Hipotesis, uji hipotesis terdiri dari: 1) Uji Korelasi Product Moment dan 2) Uji Korelasi Ganda.

\section{HASIL DAN PEMBAHASAN}

\section{Hasil Data Keseimbangan $\left(X_{1}\right)$}

Data hasil kemampuan keseimbangan siswa peserta ekstrakurikuler sepakbola SMPN 2 Kembaran dapat dilihat pada Tabel 1.

Tabel 1. Hasil analisis deskriptif variabel keseimbangan

\begin{tabular}{llll}
\hline Klasifikasi & Kelas Interval & Frek & $\%$ \\
\hline Sangat Baik & $\geq 59$ & 4 & 6,6 \\
Baik & $52-58$ & 20 & 33,4 \\
Cukup & $45-51$ & 28 & 46,6 \\
Kurang Baik & $38-44$ & 5 & 8,4 \\
Sangat Kurang & $\leq 38$ & 3 & 5 \\
\hline
\end{tabular}

Dari Tabel 1 dapat diketahui bahwa tingkat keseimbangan siswa peserta ekstrakurikuler sepakbola di SMP N 2 Kembaran ada 4 siswa yang memiliki keseimbangan sangat baik dengan presentase $6,6 \%$, ada 20 siswa yang memiliki keseimbangan baik dengan presentase $33,4 \%$, ada 28 siswa yang memiliki keseimbangan cukup dengan presentase $46,6 \%$, ada 5 siswa yang memiliki keseimbangan kurang baik dengan presentase 8,4\% dan ada 3 orang siswa yang memiliki keseimbangan sangat kurang dengan presentase $5 \%$. Dari hasil itu diketahui bahwa presentase tertinggi tingkat keseimbangan siswa berada pada kategori cukup.

\section{Hasil Data Kelentukan Pergelangan Kaki $\left(X_{2}\right)$}

Data hasil kelentukan siswa peserta 
ekstrakurikuler sepakbola SMPN 2 Kembaran dapat dilihat pada Tabel 2.

Tabel 2. Data Hasil Kelentukan Pergelangan Kaki

\begin{tabular}{llll}
\hline Klasifikasi & Kelas Interval & Frek & $\%$ \\
\hline Sempurna & $>35.00$ & 2 & 3,3 \\
Baik & $35.00-32.51$ & 1 & 1,7 \\
Cukup & $32.50-29.51$ & 9 & 15 \\
Kurang & $29.50-26.50$ & 24 & 40 \\
Buruk & $<26.50$ & 24 & 40 \\
\hline
\end{tabular}

Dari Tabel 2 dapat diketahui bahwa tingkat kelentukan pergelangan kaki siswa peserta ekstrakurikuler sepakbola di SMP N 2 Kembaran ada 2 siswa yang memiliki kelentukan pergelangan kaki sangat baik dengan presentase 3,3\%, ada 1 siswa yang memiliki kelentukan pergelangan kaki baik dengan presentase $1,7 \%$, ada 9 siswa yang memiliki kelentukan pergelangan kaki cukup dengan presentase $15 \%$, ada 24 siswa yang memiliki kelentukan pergelangan kaki kurang baik dengan presentase $40 \%$ dan ada 24 orang siswa yang memiliki kelentukan pergelangan kaki sangat kurang dengan presentase $40 \%$. Dari hasil itu diketahui bahwa presentase tertinggi tingkat kelentukan pergelangan kaki siswa berada pada kategori Kurang dan Buruk.

Hasil Kemampuan Shooting (Y).

Data hasil kemampuan shooting siswa peserta ekstrakurikuler sepakbola SMPN 2 Kembaran dapat dilihat pada Tabel 3.

Tabel 3. Hasil analisis statistik deskriptif variabel shooting

\begin{tabular}{llll}
\hline Klasifikasi & Kelas Interval & Frek & $\%$ \\
\hline Sangat Baik & $\geq 136$ & 6 & 10 \\
Baik & $118-135$ & 14 & 23,4 \\
Cukup & $101-117$ & 11 & 18,3 \\
Kurang Baik & $84-100$ & 29 & 48,3 \\
Sangat Kurang & $\leq 33$ & 0 & 0 \\
\hline
\end{tabular}

Dari Tabel 3 dapat diketahui bahwa kemampuan shooting siswa peserta ekstrakurikuler sepakbola di SMP N 2 Kembaran ada 6 siswa yang memiliki kemampuan shooting sangat baik dengan presentase $10 \%$, ada 14 siswa yang memiliki kemampuan shooting baik dengan presentase $23,4 \%$, ada 11 siswa yang memiliki kemampuan shooting cukup dengan presentase $18,3 \%$, ada 29 siswa yang memiliki kemampuan shooting kurang baik dengan presentase $48,3 \%$ dan tidak ada siswa yang kemampuan shootingnya sangat kurang. Dari hasil itu diketahui bahwa presentase tertinggi kemampuan shooting siswa berada pada kategori Kurang Baik.

\section{Hasil Uji Prasyarat}

Uji prasyarat yang dilakukan terdiri dari uji normalitas data, uji linearitas data dan uji homogenitas data. Hasil dari masing-masing uji dapat dilihat pada deskripsi dibawah ini.

\section{Uji Normalitas}

Uji Kolmogorov Smirnov digunakan untuk menguji normalitas data, karena jumlah sampel yang lebih dari 50. Data dikatakan normal jika nilai Signifikansi lebih besar dari 0,05 (Sig> 0,05). Hasil uji normalitas data dapat dilihat pada Tabel 4

Tabel 4. Uji Normalitas Data One-Sample Kolmogorov-Smirnov Test

\begin{tabular}{lccc}
\hline & $\begin{array}{c}\text { Keseim- } \\
\text { bangan }\end{array}$ & Kelentukan & Shooting \\
\hline $\mathrm{N}$ & 60 & 60 & 60 \\
$\begin{array}{l}\text { Kolmogorov- } \\
\text { Smirnov }\end{array}$ & 1.503 & .718 & .600 \\
$\begin{array}{l}\text { Asymp. Sig. } \\
\text { (2-tailed) }\end{array}$ & .022 & .680 & .865 \\
\hline
\end{tabular}

Dari Tabel 4 diketahui bahwa nilai signifikansi keseimbangan adalah 1,503, nilai signifikansi kelentukan pergelangan kaki adalah 0,71 dan nilai signifikansi shooting adalah 0,60 yang artinya nilai tersebut lebih besar dari 0,05 , sehingga dapat dikatakan bahwa data yang telah diteliti terdistribusi normal.

\section{Uji Linearitas}

Uji linieritas menggunakan Uji Ramsey Reset Test. Kriteria linearitas yang digunakan adalah $\mathrm{F}_{\text {hitung }}<\mathrm{F}_{\text {tabel }}$ dengan taraf signifikansi 0,05 . Hasil uji linearitas dapat dilihat pada Tabel 5

Dari Tabel 5 diketahui bahwa nilai ${ }_{\text {Fhitung }}$ $(1,20)<{ }_{\text {Ftabel }}(2,00)$ dan nilai signifikansi sebesar 0,986 $(>0,05)$, sehingga dapat disimpulkan jika data keseimbangan dengan data kemampuan shooting pada penelitian ini linear. 
Tabel 5. Uji Linearitas Data

\begin{tabular}{llllll}
\hline & $\begin{array}{l}\text { Sum of } \\
\text { Squares }\end{array}$ & Df & $\begin{array}{c}\text { Mean } \\
\text { Square }\end{array}$ & F & Sig. \\
\hline Linearity & 345.303 & 1 & 345.303 & .265 & .609 \\
$\begin{array}{l}\text { Devia- } \\
\text { tion from } \\
\text { Linearity }\end{array}$ & 2297.115 & 8 & 287.139 & .120 & .986 \\
\hline
\end{tabular}

Tabel 6. Uji Linearitas kelentukan pergelangan kaki

\begin{tabular}{lccccc}
\hline & $\begin{array}{c}\text { Sum of } \\
\text { Squares }\end{array}$ & Df & $\begin{array}{c}\text { Mean } \\
\text { Square }\end{array}$ & F & Sig. \\
\hline Linearity & 7884.889 & 1 & 7884.889 & 8.433 & .006 \\
$\begin{array}{l}\text { Devia- } \\
\text { tion from } \\
\text { Linearity }\end{array}$ & 27290.111 & 23 & 1186.527 & 1.269 & .257 \\
\hline
\end{tabular}

Dari tabel diatas, diketahui bahwa nilai Fhitung $(1,26)<$ Ftabel $(2,00)$ dan nilai signifikansi sebesar 0,257 $(>0,05)$, sehingga dapat disimpulkan jika data kelentukan kaki dengan data kemampuan shooting pada penelitian ini linear.

\section{Uji Homogenitas}

Data hasil uji homogenitas dapat dilihat pada Tabel 7 .

Tabel 7. Uji Homogenitas Data

\begin{tabular}{lllll}
\hline Data & $\begin{array}{l}\text { Levene } \\
\text { Statistic }\end{array}$ & df1 & df2 & Sig. \\
\hline Keseimbangan & 1.373 & 1 & 108 & .740 \\
Kelentukan & 1.513 & 1 & 108 & .987 \\
\hline
\end{tabular}

Dari Tabel 7 diketahui bahwa nilai signifikansi keseimbangan $(\mathrm{p}=0,740)>0,05$ dan nilai signifikansi elentukan $(p=0,987)>0,05$, sehingga dengan hasil tersebut dapat disimpulkan bahwa data bersifat homogen.

\section{Hasil Uji Hipotesis}

Uji hipotesis yang dilakukan terdiri dari Uji Korelasi Product Moment dan 2) Uji Korelasi Ganda.

\section{Hubungan antara Keseimbangan dengan Kemampuan Shooting}

Uji hipotesis pertama menggunakan uji korelasi product moment dengan membandingkan antara hasil keseimbangan dengan hasil kemampuan shooting siswa, hasil analisis dapat dilihat pada tabel 8 dibawah ini.
Tabel 8. Uji Hipotesis Keseimbangan

\begin{tabular}{llll}
\hline Korelasi & $\mathrm{R}_{\text {hitung }}$ & $\mathrm{R}_{\text {tabel }}$ & Keterangan \\
\hline $\begin{array}{l}\text { Keseimban- } \\
\text { gan dengan }\end{array}$ & 0,071 & 0,254 & $\begin{array}{l}\text { Tidak Ber- } \\
\text { hubungan }\end{array}$ \\
$\begin{array}{l}\text { Kemampuan } \\
\text { Shooting }\end{array}$ & & & \\
\hline
\end{tabular}

Dari Tabel 8 diketahui bahwa nilai $R_{\text {hi- }}$ sebesar 0,071 sedangkan nilai $R_{\text {tabel }}$ dengan jumlah $n=60$ adalah 0,254. Maka nilai $\mathrm{R}_{\text {hitung }}<\mathrm{R}_{\text {tabel(60) }}$ yang artinya tidak ada hubungan antara keseimbangan dengan kemampuan shooting.

\section{Hubungan antara Kelentukan Pergelangan kaki dengan kemampuan shooting.}

Uji hipotesis pertama menggunakan uji korelasi product moment dengan membandingkan antara hasil kelentukan pergelangan kaki dengan hasil kemampuan shooting siswa, hasil analisis dapat dilihat pada Tabel 9.

Tabel 9. Uji Hipotesis Kelentukan Pergelangan Kaki

\begin{tabular}{llll}
\hline Korelasi & $R_{\text {hitung }}$ & $R_{\text {tabel }}$ & Keterangan \\
\hline Kelentukan & & & \\
Pergelangan & 0,341 & 0,254 & Berhubungan \\
kaki dengan & & & \\
Kemampuan & & & \\
Shooting & & & \\
\hline
\end{tabular}

Dari Tabel 9 diketahui bahwa nilai $\mathrm{R}_{\mathrm{hi}}$ tung sebesar 0,341 sedangkan nilai $\mathrm{R}_{\text {tabel }}$ dengan jumlah $n=60$ adalah 0,254 . Maka nilai $R_{\text {hitung }}$ $>\mathrm{R}_{\text {tabel(60) }}$ yang artinya ada korelasi antara kelentukan pergelangan kaki dengan kemampuan shooting.

\section{Hubungan antara Keseimbangan dan Kelen- tukan Pergelangan Kaki dengan Kemampu- an Shooting}

Uji hipotesis ketiga menggunakan uji korelasi berganda dengan membandingkan antara hasil keseimbangan dan kelentukan pergelangan kaki dengan hasil kemampuan shooting siswa, hasil analisis dapat dilihat pada Tabel 10 . 
Tabel 10. Uji hipotesis keseimbangan dan kelentukan pergelangan kaki dengan kemampuan shooting

\begin{tabular}{lccc}
\hline Korelasi & $R_{\text {hitung }}$ & $R_{\text {tabel }}$ & Keterangan \\
\hline $\begin{array}{l}\text { Keseimbangan, } \\
\text { Kelentukan }\end{array}$ & 0,129 & 0,254 & Tidak Ber- \\
$\begin{array}{l}\text { Pergelangan } \\
\text { kaki dan Shoot- }\end{array}$ & & & hubungan \\
ing & & & \\
\hline
\end{tabular}

Dari Tabel 10 diketahui bahwa nilai $\mathrm{R}_{\mathrm{hi}-}$ tung sebesar 0,129 sedangkan nilai $\mathrm{R}_{\text {tabel }}$ dengan jumlah $n=60$ adalah 0,254 . Maka nilai $R_{\text {hitung }}<$ $\mathrm{R}_{\text {tabel(60) }}$. Dapat disimpulkan bahwa tidak ada korelasi antara kelentukan pergelangan kaki dengan kemampuan shooting.

\section{Pembahasan}

Pada permainan sepakbola memang terdapat teknik yang perlu dikuasai oleh setiap pemain, salah satunya adalah shooting. Untuk menguasai teknik dasar shooting, diperlukan latihan yang terprogram dan teridiri dari berbagai macam aspek serta penerapan metode latihan. Pendekatan teknik dan taktik merupakan salah satu contoh yang dapat digunakan untuk meningkatkan keterampilan shooting. Hal ini sejalan dengan penelitian dari (Festiawan, 2020) yang menyimpulkan bahwa ada pengaruh yang signifikan antara latihan teknik dan taktik terhadap keterampilan shooting dengan nilai signifikansi 0,000.

Penelitian ini memiliki tujuan untuk mengetahui korelasi antara keseimbangan dan kelentukan pergelangan kaki dengan kemampuan shooting siswa peserta ekstrakurikuler sepakbola SMP Negeri 2 Kembaran Banyumas. Hasil-hasil penelitian diantaranya:

\section{Hubungan Keseimbangan Dengan Kemam- puan Shooting}

Dari hasil uji korelasi keseimbangan dengan kemampuan shooting diperoleh nilai $\mathrm{r}_{\mathrm{x} 1 . \mathrm{y}}=0,071<\mathrm{r}_{(0,05)(60)}=0,254$ nilai ini menunjukan bahwa tidak terdapat hubungan yang signifikan diantara keduanya. Dalam penelitian (Erkut et al., 2014) menyebutkan bahwa ada beberapa faktor yang mempengaruhi keseimbangan tubuh, salah satunya ialah lingkungan.

Penelitian lain menyebutkan jika keseimbangan pemain yang baik merupakan salah satu faktor yang dapat menunjang kemampuan shooting dalam permainan sepakbola dengan faktor pendukung yaitu kekuatan otot, karena keseimbangan yang baik pun harus ditunjang dengan otot, sendi serta jaringan lunak lainnya (Abdurahman et al., 2014). Dalam penelitian (Mekayanti et al., 2015) keseimbangan juga dapat dipengaruhi oleh usia, motivasi, kondisi, lingkungan, kelelahan, pengaruh obat dan pengalaman terdahulu.

Penelitian terdahulu sampel merupakan SSB dan SMA. Pada penelitian ini menggunakan sampel anak SMP tentunya perbedaan karakteristik sampel sangat menentukan faktor dalam keseimbangan yang baik. Karena keseimbangan yang baik membutuhkan faktor penunjang lainnya.

Keseimbangan juga membutuhkan faktor dari berat badan seseorang dan tinggi badan seseorang karena dengan berat badan dan tinggi badan yang tidak seimbang maka akan mempengaruhi keseimbangan dari seseorang, dalam penelitian ini belum mencantumkan kriteria berat badan dan tinggi badan untuk tes keseimbangan, sehingga sampel dinyatakan semuanya sama. Penelitian berikutnya ini bisa menjadi dasar bahwa pada saat melaksanakan tes keseimbangan faktor dari berat badan dan tinggi badan untuk dimasukkan dalam kriteria penetuan sampel.

\section{Hubungan Antara Kelentukan Pergelangan Kaki Dengan Kemampuan Shooting}

Dari hasil uji korelasi antara kelentukan pergelangan kaki dengan kemampuan shooting diperoleh nilai $\mathrm{r}_{\mathrm{x} 2 \mathrm{y}}=0,341>\mathrm{r}_{(0,05)(60)}=$ 0,254, nilai ini menunjukan bahwa terdapat hubungan yang signifikan diantara keduanya. Hasil ini tentu menunjukkan bahwa seorang pemain sepakbola perlu memiliki kelentukan pergelangan kaki yang baik karena memiliki hubungan yang positif dengan kemampuan shooting yang artinya jika seseorang memiliki kelentukan pergelangan kaki yang baik maka kemampuan shootingnya pun akan baik. Penelitian lain menyebutkan bahwa kelentukan pergelangan kaki berpengaruh signifikan terhadup kemampuan shooting, karena semakin besar ruang sendi di pergelangan kaki maka efektifitas gerakannya akan semakin baik salah satunya untuk melakukan shooting ke gawang (Raharjo et al., 2017).

Kelentukan pergelangan kaki yang baik akan membantu seorang pemain dalam hal ini yang sangat sering melakukan shooting merupakan striker untuk melakukan shooting yang baik ke gawang lawan. Sehingga akan menguntungkan tim apabila memiliki striker dengan kualitas shooting yang sangat baik. 
Hal ini sejalan dengan penelitian (Wibowo, 2015) pada permainan sepakbola untuk meningkatkan shooting bahwa kelentukan pergelangan kaki sangat dibutuhkan, karena apabila pergelangan kaki memiliki kelentukan yang baik maka pada saat akan melakukan shooting ruang gerak sendi akan terbuka maksimal sehingga pada saat akan menyentuh bola memiliki power yang cukup untuk melakukan shooting.

\section{Hubungan Antara Keseimbangan dan Ke- lentukan Pergelangan Kaki Dengan Kemam- puan Shooting.}

Dari hasil uji korelasi antara keseimbangan dan Kelentukan Pergelangan Kaki dengan kemampuan shooting diperoleh nilai $r_{x 1, x 2, y}=0,129<r_{(0,05)(60)}=0,254$, nilai ini menunjukan bahwa tidak terdapat hubungan yang signifikan diantara kedua variabel $\mathrm{x}$ dengan variabel y.

Dengan hasil ini maka diketahui bahwa keletukan pergelangan kaki dan keseimbangan jika disatukan tidak ada hubungannya dengan kemampuan shooting, dengan kata lain jika kelentukan pergelangan kaki seorang pemain bagus dan keseimbangan pemain bagus maka belum tentu memiliki kemampuan shooting yang bagus pula.

Hal ini sejalan dengan penelitian Rajidin (2014) yang menyebutkan bahwa tidak ada korelasi antara kelentukan dan $b=$ keseimbangan secara bersama-sama terhadap kemampuan shooting seorang pemain. Dengan ini maka seorang pelatih perlu mempertimbangkan faktor-faktor penentu yang perlu ditingkatkan, salah satunya adalah kelentukan pergelangan kaki. Namun tidak perlu melatih keseimbangan tubuh terlalu keras karena tidak ada pengaruhnya terhadap kemampuan shooting.

\section{SIMPULAN}

Dari hasil dan pembahasan penelitian ini dapat ditarik kesimpulan bahwa 1) Keseimbangan tidak memiliki korelasi dengan kemampuan shooting, 2) Kelentukan pergelangan kaki memiliki korelasi dengan kemampuan shooting, dan 3) Keseimbangan dan kelentukan pergelangan kaki tidak berkorelasi dengan kemampuan shooting.

\section{DAFTAR PUSTAKA}

Abdurahman, B. B., Adiputra, N., \& Sugijanto. (2014) Pelatihan Core Stability Dan Balance Board Exercise Lebih Baik Dalam Meningkatkan Keseimban- gan Dibandingkan Dengan Balance Board Exercise Pada Mahasiswa Usia 18 - 24 Tahun Dengan Kurang Aktivitas Fisik. Sport and Fitness Journal, 2(1), 134-149.

Bryson, J. (2012). Soccer Coaching Manual. LA84 Foundation. Los Angeles: CA.

Budiyono, K., Yusuf, M., \& L, R. P. (2018). Hubungan Kekuatan Otot Tungkai, Kelentukan dan Pergelangan Kaki Terhadap Tendangan Jarak Jauh pada Klub Sepak Bola SSB UTP Surakarta Tahun 2018. Jurnal Ilmiah SPIRIT, 18(1), 39-47.

Erkut, O., Ramazanoglu, N., Uzun, S., Camliguney, A. F., Bozkurt, S., Tiryaki, C., Kucuk, V., Sirmen, B., \& Karadenizli, Z. I. (2014). Comparision of dynamic and static balance in adolescents handball and soccer players. Turkish Journal of Sport and Exercise, 16(1), 47-47. https://doi.org/10.15314/ tjse. 201416111

Festiawan, R. (2020). Pendekatan Teknik dan Taktik: Pengaruhnya Terhadap Keterampilan Bermain Futsal. Gelanggang Olahraga: Jurnal Pendidikan Jasmani Dan Olahraga, 3(2), 143-155. https://doi.org/https:// doi.org/10.31539/jpjo.v3i2.1080

Festiawan, R., Nurcahyo, P. J., \& Pamungkas, H. J. (2019). Pengaruh Latihan Small Sided Games Terhadap Kemampuan Long Pass pada Peserta Ekstrakurikuler Sepakbola. Media Ilmu Keolahragaan Indonesia, 9(1), 18-22. https://doi.org/https://doi. org/10.15294/miki.v9i1.20666

Istofian, R. S., \& Amiq, F. (2016). Metode Drill Untuk Meningkatkan Teknik Menendang Bola (Shooting) Dalam Permainan Sepakbola Usia 13-14 Tahun. Jurnal Kepelatihan Olahraga, 1(1), 105-113.

Jibriel, K. (2013). Hubungan Panjang Tungkai, Kekuatan Otot Tungkai, dan Kelentukan Pergelangan Kaki Terhadap Tendangan Jarak Jauh Pemain U-15 SSB Tunas Muda Banyubiru Kab. Semarang Tahun 2012. Skripsi. Universitas Negeri Semarang.

Mekayanti, A., Indrayani, \& Dewi, K. (2015). Optimalisasi Kelenturan (Flexibelity), Keseimbangan (Balance), dan Kekuatan (Strength) Tubuh Manusia secara Instan dengan Menggunakan "Secret Method." Jurnal Virgin, 1(1), 40-49.

Mu'is, A. (2014). Analisis Kondisi Fisik Terhadap Keterampilan Menendang Bola Ke Arah Gawang (Shooting). Jurnal Kesehatan Olahraga, 2(3), 111-122.

Mubarok, A. (2011). Kemampuan Shooting Sepakbola Ditinjau Dari Power Otot Tungkai, Koordinasi Mata-Kaki dan Keseimbangan Dinamis Pada Siswa Sekolah Sepakbola (SSB) Muda United Mujur Usia 15-17 Tahun Kecamatan Kroya Tahun 2010/ 2011. Skripsi. Universitas Sebelas Maret.

Putra, D., \& Ridwan, M. (2010). Kekuatan Otot Tungkai, Koordinasi Mata-Kaki dan Keseimbangan Berhubungan dengan Kemampuan Shooting Sepakbola. Skripsi. Universitas Negeri Padang.

Raharjo, K., Syafrial, \& Sugiyanto. (2017). Upaya Meningkatkan Hasil Akurasi Shooting Olahraga Sepakbola Melalui Media Lingkaran Karet Ban Pada Siswa Kelas XI IPS 2 SMA Negeri 03 Bengkulu. Jurnal Kinestetik, 1(2), 92-96. https://doi.org/10.33369/ jk.v1i1.3369

Rajidin. (2014). Model Latihan Shooting Ke Gawang Pada Mahasiswa Ukm Sepak Bola IKIP-PGRI Pontianak. Jurnal Pendidikan Olah Raga, 3(2), 192-201.

Saifuddin, A., \& Abdurrahman. (2017). Hubungan Keseimbangan Dengan Shooting Dalam Permainan Sepakbola (Pada Siswa SMA NEGERI 1 Rundeng Kota Subulussalam Tahun 2016). Jurnal Ilmiah Mahasiswa Pendidikan Jasmani, Kesehatan Dan Rekreasi, 
3(3), 225-233.

Sugiyono. (2016). Metodologi Penelitian Kuantitatif, Kualitatif, dan R\&D. CV Alfabeta: Jakarta.

Wicaksono, P. N., Kusuma, I. J., Festiawan, R., Widanita, N., \& Anggraeni, D. (2020). Penerapan pendekatan saintifik terhadap pembelajaran pendidikan jasmani materi teknik dasar passing sepak bola. Jur- nal pendidikan jasmani Indonesia, 16(1), 41-54

Wibowo, D. A. (2015). Hubungan Kekuatan Otot Tungkai dan Kelentukan Pergelangan Kaki Terhadap Keterampilan Shooting Pada Peserta Kegiatan Ekstrakurikuler Sepakbola Di SMK Ahmad Yani Kediri Tahun Ajaran 2014-2015. Skripsi. Universitas Nusantara PGRI Kediri. 